IRSTI 34.29 .25

\author{
${ }^{1}$ B.A. Turalin, ${ }^{1}$ N.V. Kurbatova, ${ }^{1}$ M.S. Kurmanbayeva, \\ ${ }^{1 *}$ K.T. Abidkulova, ${ }^{2}$ A.A. Bazargaliyeva, ${ }^{3}$ A.N. Kupriyanov \\ 'al-Farabi Kazakh National University, Almaty, Kazakhstan \\ ${ }^{2}$ Aktobe Regional State University named after K. Zhubanov, Aktobe, Kazakhstan \\ ${ }^{3}$ Institute of Human ecology, Siberian branch of the Russian Academy of Science, Kemerovo, Russia \\ *e-mail: Karime.Abidkulova@kaznu.kz
}

\title{
Anatomy of the vegetative organs of rare and endangered species Crambe tatarica Sebeok. (Brassicaceae) growing in the conditions of the Aktobe region
}

\begin{abstract}
The article presents the results of a study of the anatomy of the vegetative organs (roots, leaves and petioles) of rare and endangered plant species Crambe tatarica Sebeok, growing in the Aktobe region of Kazakhstan. The studied plants were collected from two populations: the first population was found in the chalk mountains of Akshatau, in the vicinity of the village of Koktogay, the Wilsky district, and the second population was found in the chalk mountains of Ishkargantau, the village of Karabulak, the Khobdinsky district. This species belongs to mesoxerophytes and calcephytes. According to the available literature, in Kazakhstan C. tatarica has the status of $3 \mathrm{~b}(\mathrm{R})$ - rare, relict species. Some representatives of the genus Crambe L. are important economic species because they are oilseed, melliferous, fodder and medicinal plants. Study of the roots of $C$. tatarica revealed the presence of the phloem parenchyma, radial rays, xylem parenchyma and cells of a mechanical tissue, brachisclereids. In the internal structure of leaf numerous starch grains were noted in the parenchyma; brachisclereides were often found on periphery of the leaf, and sclerenchyma cells were apparent in the center of vascular bundles. Large number of vascular bundles was noted in the petioles; the outer wall of the epidermis cells was thickened. In the studied organs, no large cells with a liquid content were found. The obtained information on features of the anatomical structure of roots, leaves and petioles of $C$. tatarica will be used in the future for diagnostics of the raw plant material, and in the studies of its phytochemical composition.
\end{abstract}

Key words: anatomical, morphological features, vegetative organs, rare, endangered species.

\section{Introduction}

Study of the biology of rare and endangered plant species as the most vulnerable elements of changing ecosystems is closely related to the conservation of biological diversity. Such species are carriers of a valuable biological information; they are good indicators of a scientific value of a certain territory for its further assignment to the status of specially protected. One of such species is Crambe (C.) tartarica Sebeok.

Genus Crambe L. has a broad area of distribution, from the Macaronesian archipelago to the west of China and North India and from the Arctic Polar Circle on the Scandinavian Peninsula to $5^{\circ}$ Latitude South in the north of Tanzania. This genus is represented in Macaronesia, Euro-Siberian, Mediterranean, Sindico-Sahara, Iranian-Turkish, and Sudan-Zambezian (Ethiopia and Tanzania) regions [1].

A critical review of the species composition of the genus Crambe is presented in the works of I.I. Khalilov [2]. According to the author, genus includes 33 species belonging to 7 sections and 6 subsections. Prina [3] provided a taxonomic review of 16 species and 5 intraspecific taxa of the genus Crambe encountered from Eastern and Northern Europe to Central Asia. In Kazakhstan, there are four species of Crambe: C. tatarica, C. kotschyana Boiss., $C$. edentula Fisch. et C.A. Mey. ex Karelin, and $C$. orientalis L. [4], but only one species, C. tatarica, is included in the latest edition of the Red Book of Kazakhstan as a rare species of the II $^{\text {nd }}$ category [5].

C. tatarica is a southern European and Mediterranean species. This is a perennial polycarpic, up to $90 \mathrm{~cm}$ tall. Root $60-120 \mathrm{~cm}$ long, fusiform, juicy. 
Plants single- or multi-stemmed, stems erect, with sparse short stiff hairs, later naked. Leaves fleshy, grey-green in colour; basal leaves large, on petioles, up to $30 \mathrm{~cm}$ in length and $20 \mathrm{~cm}$ in width, twice pinnate, with oblong-linear, toothed or incised lobes, with stiff hairs, especially on the abaxial side, later exposed; the uppermost leaves are linear, entire. Flowers in dense paniculate inflorescence, with honey smell; white, $4.5-5 \mathrm{~mm}$ in length. Pods spherical, the upper segment of the pod is $4-5 \mathrm{~mm}$ in diameter, tetragonous, mesh-rugose, with four sharply prominent ribs, on the stalks up to $10 \mathrm{~mm}$ in length. Dispersal is by seeds. Flowers are produced in April - May, fruits in June - August. The species occurs in steppes, on stony-gravelly slopes, and chalky outcrops. In Kazakhstan, it is found in the Northern Pre-Caspian, Aktobe, Atyrau and Kostanay regions, where the eastern border of its range is located. Outside of Kazakhstan, the species is found in the south of the European part of the former USSR, in the Crimea, Caucasus, Western Siberia (exclusively as an alien species) and in southern Europe [5-8].

The rarity of the species, its vulnerability to anthropogenic impact resulted in the inclusion of C. tatarica in the Red Books of the Ukraine, Moldova and southern regions of Russia (Kursk, Belgorod, and Volgograd regions) $[9 ; 10]$.

Some members of the genus Crambe L. are of great importance as oilseeds, melliferous, fodder and medicinal plants, eg., C. abyssinica Hochst. The protein content of the seeds of this species is $45-50 \%$, and the oil content is up to $35 \%$; the latter contains $55-60 \%$ of erucic acid [11]. Such characteristics make it a valuable plant material in the production of animal feed, biodiesel, and for some industrial and pharmaceutical applications. As a consequence, this species has been well studied [11-16].

Among Central Asian species, C. orientalis L. and C. kotschyana Boiss. have been studied in Uzbekistan $[17 ; 18]$.

C. tatarica has been studied in the Crimea and the Lugansk natural reserve [6; 7]. The composition of the oil obtained from the seeds of $C$. orientalis and C. tataria var. tataria from Turkey and the chemical composition and properties of the fibers $[19 ; 20]$ have also been studied. In their studies, scientists from the Czech Republic compared the biochemical composition of $C$. tatarica plants obtained from the Ukraine and grown in vitro and in vivo [21].

Due to the above, this species is of scientific and practical interest, which justifies its further study. It should be noted that anatomical studies of the Kazakhstani species $C$. tatarica have been carried out for the first time.

\section{Materials and methods}

As a result of the field surveys in Aktobe region, two C. tatarica populations were found: population 1, in the chalk mountains of Akshatau, in the vicinity of Koktogai settlement, Uilsky district; and population 2, in the chalk mountains of Ishkargantau, Karabulak settlement, Hobdinsky district. The studied species belongs to the Pliocene desert-steppe relics and is represented in the calcephylic floristic complex of the Aktobe region [22-24]. C. tatarica belongs to mesoxerophytes and calcephytes. According to the information on rare and endangered plants of the Aktobe region, the species has the status of $3 \mathrm{~b}$ (R) - rare, relict species [25].

Anatomical preparations were produced following the methods accepted in plant anatomy [26]. For microscopic examination, the vegetative organs of $C$. tatarica were taken. The microscopic studies were conducted using plant material, which has been fixed in a mixture of $96 \%$ ethanol, glycerine and water in a ratio of 1: 1: 1 .

In accordance with the guidelines, the cross sections of the vegetative organs were produced in the flowering phase, since it is in this phase that the structural anatomical elements of the plant organs have the greatest integrity.

The root sections were produced in the basal part of the roots, every $2-3 \mathrm{~cm}$ along their entire length. For the study, plants of a certain age were taken, but the main attention was paid to the middle-aged generative plants, which provide the bulk of the raw material for the study of the species.

Anatomical preparations were produced using a microtome with an OL-ZSO freezing device (Inmedprom, Russia), and also by hand using ordinary razors with a biconcave blade. The thickness of the anatomical sections was 10-15 microns. For quantitative analysis, morphometric parameters were measured using an MOV-1-15 eyepiece micrometer (LOMO, Russia); with a lens x 10; magnification $\mathrm{x}$ 10, 20). Microphotographs of anatomical sections were taken on an MC 300 microscope (Micros, Austria) with a CAM V400 / 1.3M video camera (jProbe, Japan).

Descriptions of morphological and anatomical characteristics were made in accordance with the requirements of the State Pharmacopoeia XI [27; 28]. 


\section{Results and discussion}

As a result of the field trips in the Aktobe region during the spring-summer of the growing season of 2018 , two populations of $C$. tatarica were found and surveyed.

Anatomical studies of the vegetative organs of $C$. tatarica showed the following results. In the anatomical structure of a root (cross section) with $10 \times 10$ and $10 \times 20$ magnification, the primary cortex and central cylinder were clearly visible. The outer layer was represented by a loose layer of periderm cells. Cells with lateral appendages, that is, root hairs, were noticed. The primary cortex consisted of thin-walled cells of the parenchyma, oval in shape and closely spaced. The primary sclerenchyma was located along the edges of the primary cortex and represented by groups of brachisclereid (isodiametric sclereides) with lignified walls. The conductive elements of the secondary phloem were thin-walled, polygonal, and brownish in colour; they were arranged in small groups. The gaps between the conductive elements were filled with parenchymal cells. Next to the phloem was the cambial ring. The xylem was represented by vessels forming radial rays. The primary xylem was of a diarch type. The xylem vessels were arranged in cords along the radii of the root in the form of rays. The larger vessels were located in the center of the root, and next to them, towards the surface of the root, were the vessels with a smaller diameter. The biometric indicators were as follows: the thickness of the primary cortex was $134.17 \pm 2.80$ $\mu m$, the diameter of the central cylinder, $85.61 \pm 7.86$ $\mu \mathrm{m}$, the area of the xylem vessels, $133.25 \pm 10.10$ $\mu \mathrm{m}^{2}$. In the center of the root there was a core parenchyma consisting of small loosely arranged cells; round-shaped starch-containing inclusions were also present (Figure 1).

In a cross section of a leaf of $C$. tatarica, large cells of the upper epidermis with poorly sinuous walls, slightly thickened cuticle layer and a small number of stomata were visible on the surface (20x); the thickness of the upper epidermis was on average $22.17 \pm$ $0.20 \mu \mathrm{m}$, and the thickness of the lower epidermis, $28.21 \pm 0.24 \mu \mathrm{m}$. The stomata on both sides of the leaf were surrounded by 2-4 periustic cells (anomocytic type). In the upper epidermis, small, rare, sessile, colorless or light brown glands consisting of 2-4 cells were found. The leaf of $C$. tatarica was a typical dorsoventral, hypostomatic leaf with the adaxial side formed by tangently elongated cells. The cells of the abaxial (spinal) epidermis had the same structure, however their dimensions were sometimes smaller.

Int. j. biol. chem. (Online)
On the adaxial (abdominal) and abaxial sides of the leaf, simple trichomes were located, mainly concentrated along the veins. Large trichomes were formed in the area of the main vein on the basal multicellular protrusions. The mesophyll was poorly differentiated. The palisade tissue was represented by three layers of cells slightly elongated perpendicular to the surface, with numerous chlorophyll-bearing inclusions. The spongy tissue was also formed by three layers of isodiametric, closely arranged cells with small intercellular spaces. The vein was a closed collateral bundle. In the leaves of population 1 (Figure 2 , a), there were two, occasionally three conductive beams in the central vein, whereas in the leaves of population 2 the number of beams reached 4-5. A parenchymal lining was formed around the group of conductive beams. In the central part, collenchyme cells were located, which can be both above and below the vein (Figure 2, c).

The diagnostic features of this species include the presence of numerous starch grains in the leaf (Figure 3 ), in the peripheral part of the leaf there were often brachisclereides or stony cells that form mechanical elements of an approximately equal diameter in all directions, otherwise they were parenchymal cells with very thick walls, and in the center of the group of conducting beams there were sufficiently developed collenchyme cells (Figure 4).

The anatomical structure of a petiole of $C$. $t a-$ tarica is characterized by the following features. The petioles of plants collected in populations 1 and $2 \mathrm{had}$ an identical structure; they were of a radial type with well-developed numerous (15-27) bundles. In cross section, a petiole had a grooved, rounded shape. The abaxial (dorsal side) was rounded, and on the side of the adaxial (abdominal) part there were scleretised parts of the petiole. The uppermost layer was represented by large epidermal cells of the oval and round shape, 15-20 $\mu \mathrm{m}$ in length and 30-45 $\mu \mathrm{m}$ in height. The outer wall of the epidermal cells was slightly thicker, up to 1-3 $\mu \mathrm{m}$. The outer wall of the epidermal cells had appendages. The cuticle was $1-1.8 \mu \mathrm{m}$ thick, evenly thickened, smooth; it evenly covered the petiole. Under the epidermal layer of cells there were from one to three layers of large collenchyme cells, 15$30 \mu \mathrm{m}$ in diameter. From the periphery to the center, there was an assimilation tissue consisting of 5-7 layers of chlorenchyma cells. The chlorenchyma thin-walled cells, round or irregular in shape, varied in size from 10 to $60 \mu \mathrm{m}$. Collateral conductive bundles of different size were arranged in an orderly manner in the central part of the petiole. 
The bundles were round and V-shaped. There were 8-10 large bundles, 3-4 of medium size and 4-5 small bundles. The parenchyma found between bundles was not lignified. The xylem of the bun- dles faced the center, and the phloem, the surface of the petiole. The mechanical tissue was well defined and formed by sclerenchyma cells, adjacent to the phloem (Figures 5 and 6).

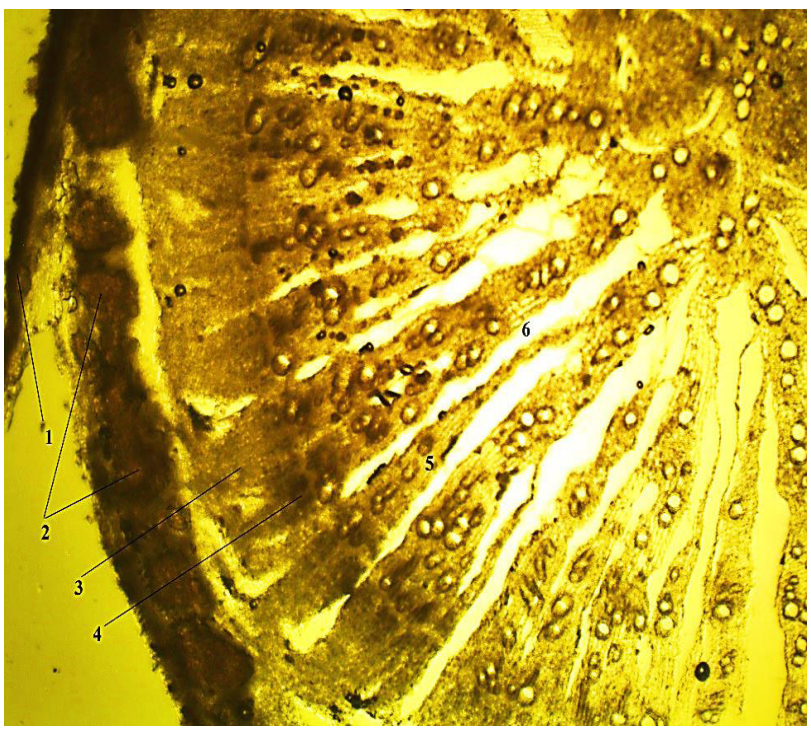

a

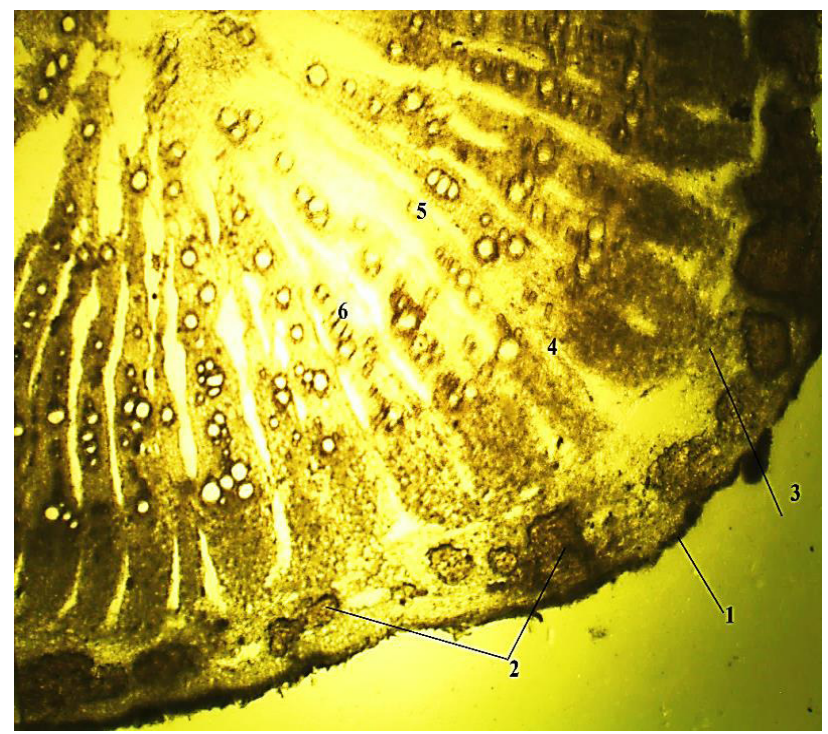

b

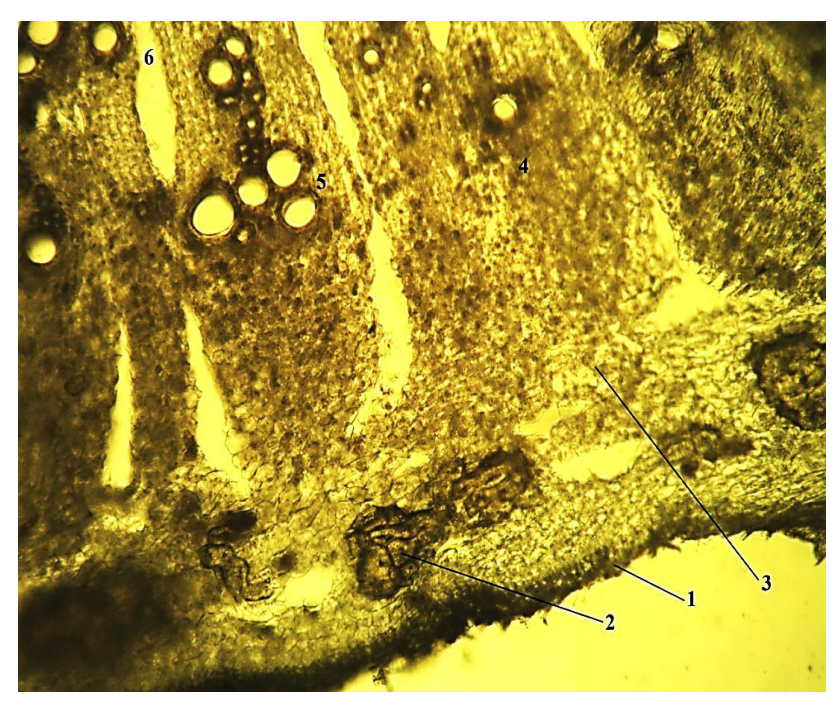

$\mathrm{c}$

Figure 1 - Anatomical section of the root

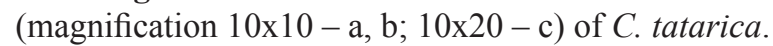

Note: 1 - periderm, 2 - brachisclereides; 3 - primary cortex; 4 - phloem; 5 -xylem; 6 - radial parenchymal rays; $\mathrm{a}$ - the first population, $\mathrm{b}$ - the second population, $\mathrm{c}$ - the general diagnostic signs of the two populations 


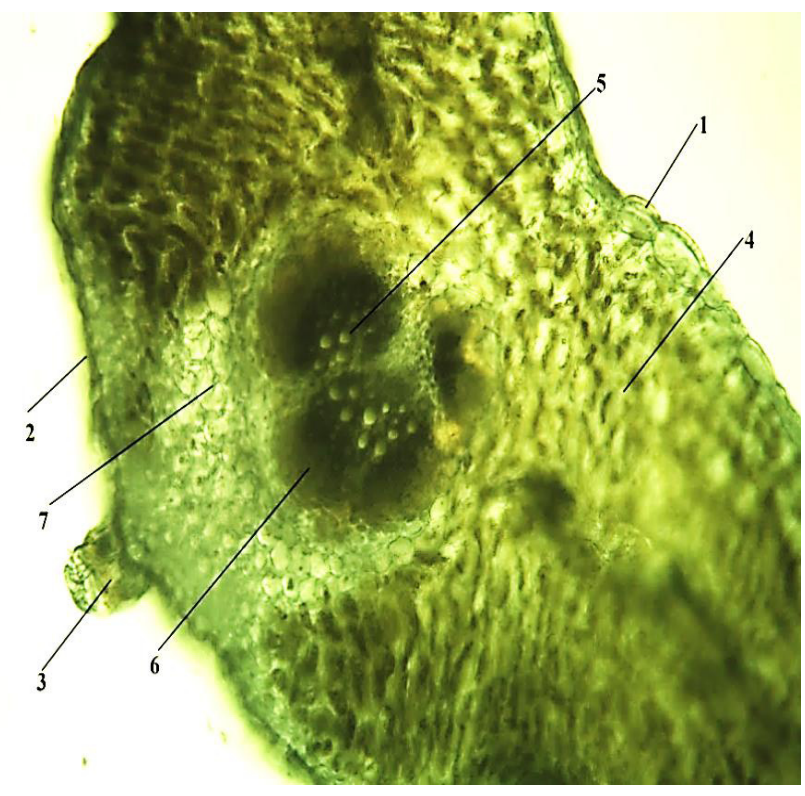

a

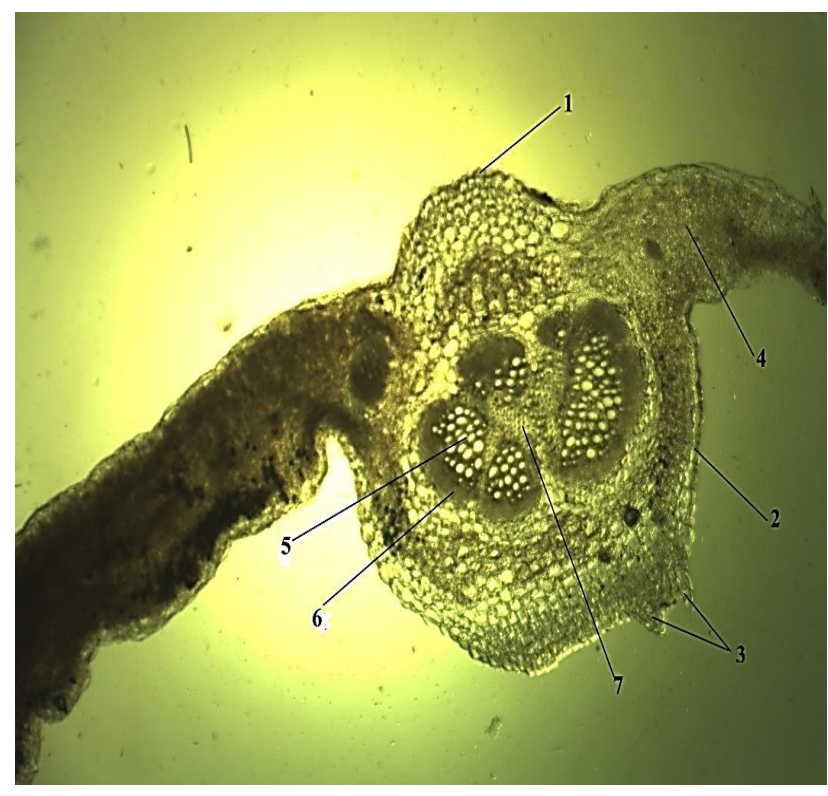

b

Figure 2 - Anatomical section of the leaf of $C$. tatarica. Note: 1 - upper epidermis, 2 - lower epidermis, 3 - trichomes with multicellular base, 4 - mesophyll,

5 -xylem, 6 - phloem, 7 - collenchyma; a - the first population (magnification10x10), $\mathrm{b}-$ the second populations (magnification $4 \times 10$ )

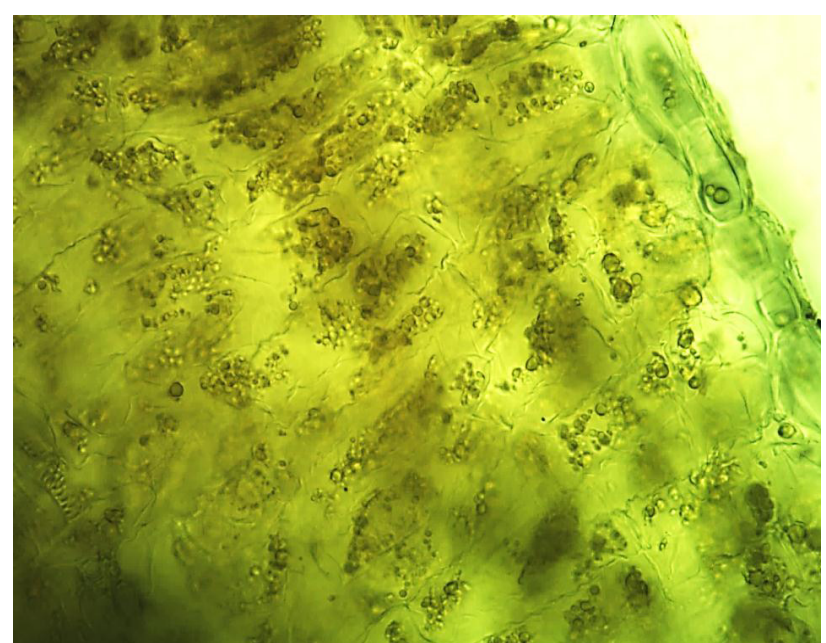

Figure 3 - Mesophyll cells of the leaf of $C$. tatarica with starchy grains (magnification $10 \times 40$ )

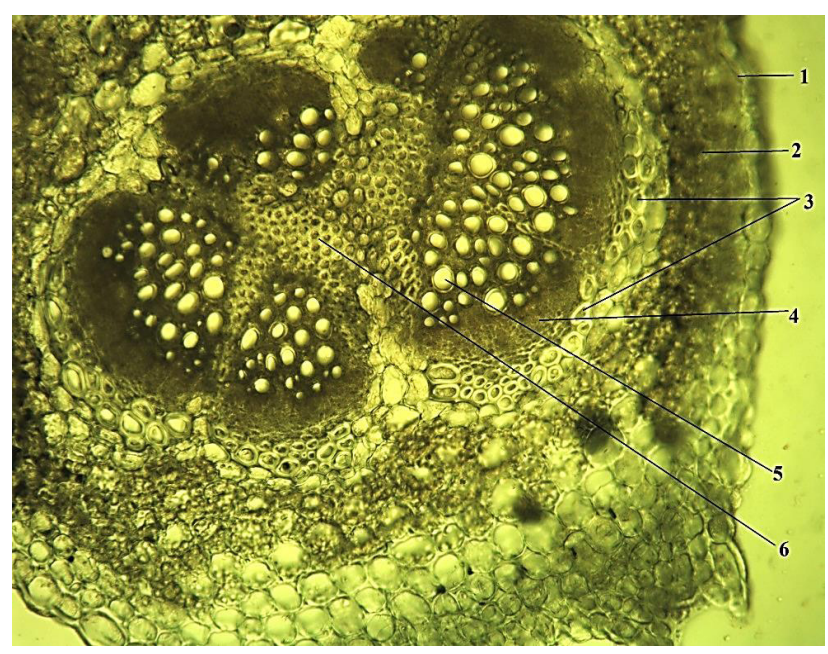

Figure 4 - Collenchyma cells in the center of the group of conducting bundles of $C$. tatarica (magnification $10 \times 40$ ). Note:

1 - lower epidermis, 2 - mesophyll, 3 - sclerenchyma, 4 - phloem, 5 - xylem vessels, 6 - collenchyma 


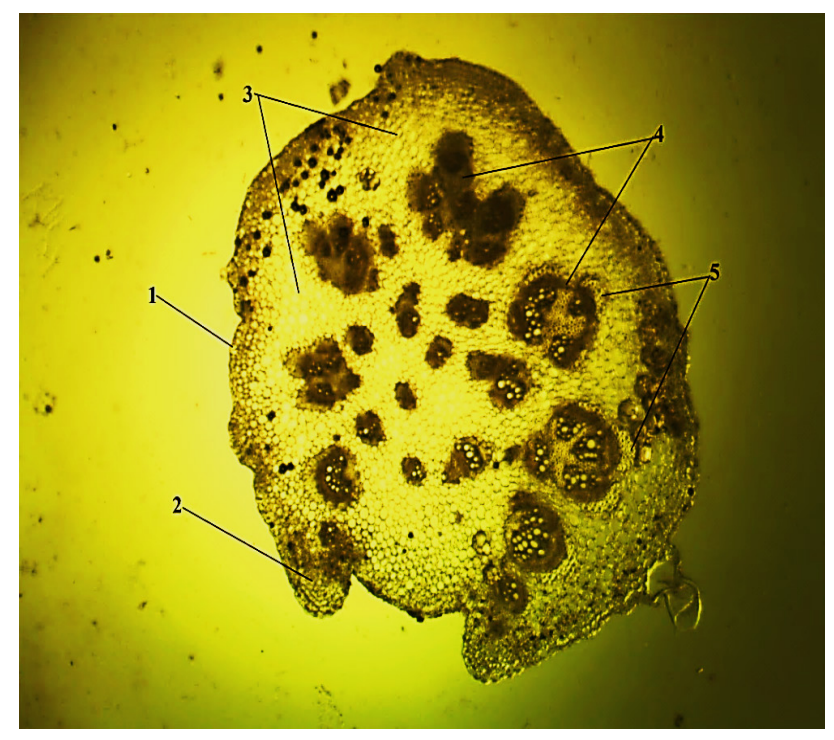

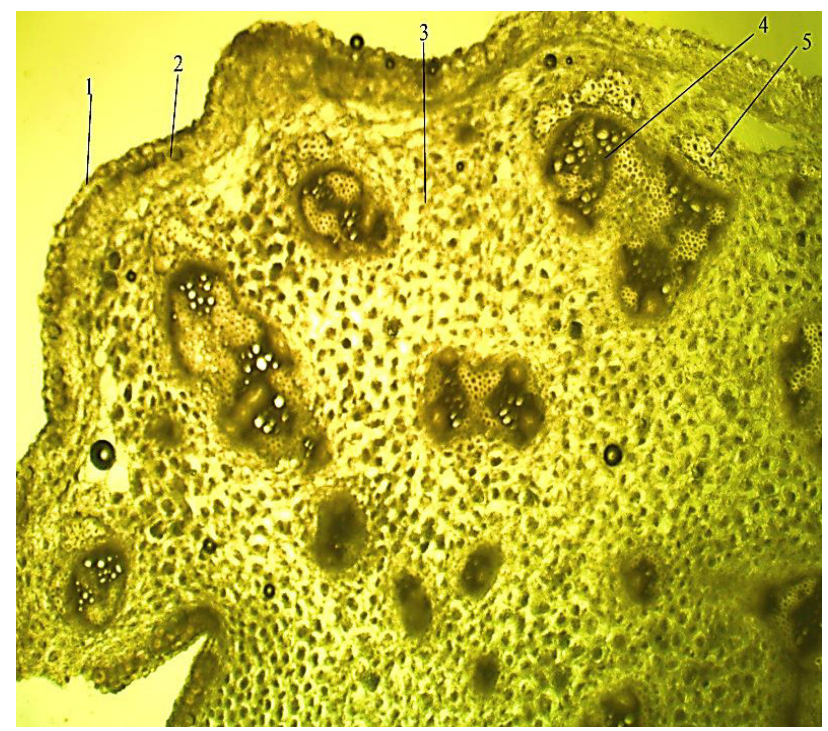

b

Figure 5 - Anatomical section of the petiole of $C$. tatarica. Note: 1 - epidermis, 2 - angle-shaped collenchyme, 3 - chlorenchyma, 4 - collateral beams, 5 - sclerenchyma; a - first population (magnification 4x10), b - second population (magnification 10x10)

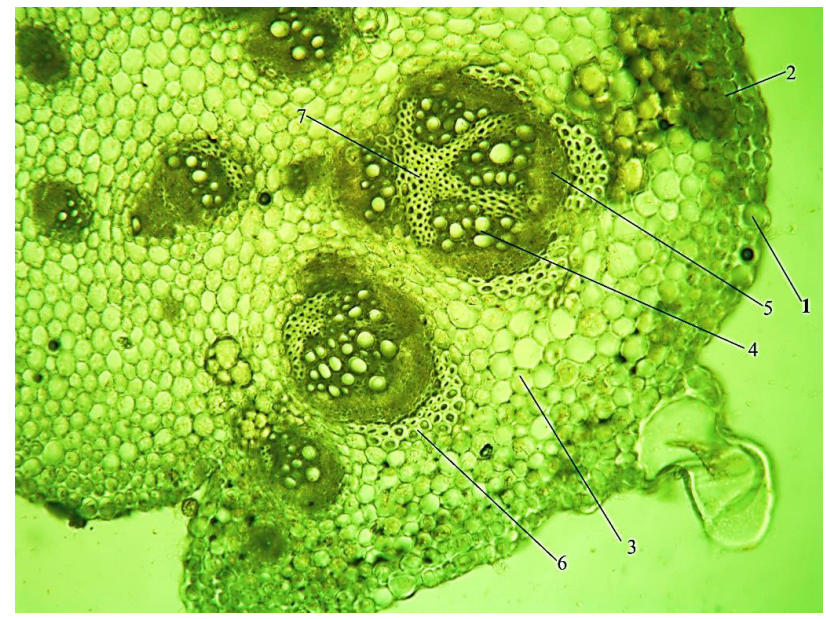

Figure 6 - Anatomical section of the petiole of $C$. tatarica, first population (magnification 10x10). Note: 1 - epidermis, 2 - angle-shaped collenchyma, 3 - chlorenchyma,

4 -xylem, 5 - phloem, 6 - sclerenchyma, 7 - collenchyme

When comparing the obtained results with the data available from the literature [6], similar features of the anatomical structure of the vegetative organs of C. tatarica were noted. Thus, the layering of the xylem and phloem parenchyma, and the well-developed primary cortex enable roots to perform the storage function, which is indicated by a large amount of starch-bearing grains in the root parenchyma. The abundance of the parenchyma in combination with weak differentiation of mechanical tissues or lack thereof is characteristic of highly specialized contractile roots, which makes it possible to retract the reproductive buds below the soil surface and thus protect them from adverse conditions. The structure of a leaf of C. tatarica revealed xeromorphic features: the presence of a thickened cuticle, weak pubescence, thickening of the outer walls of the epidermis, a small volume of intercellular spaces, and the presence of a mechanical lining of the bundle. Leaves developing in bright light had a higher degree of xeromorphism. In addition, a feature of an anatomical structure characteristic of mesophytes was revealed: the predominance of the spongy tissue over the palisade tissue.

\section{Conclusion}

Thus, as a result of the study of the anatomical structure of the vegetative parts (roots, leaves, and petioles) of the plants of $C$. tatarica, it was found that the phloem parenchyma, radial rays and xylem parenchyma were well developed in roots, which did not interfere with root contractility; brachisclereides (cells of mechanical tissue) were also present. In addition, roots were characterized by an abundance of non-lignified parenchymal tissues. In the case of leaves, diagnostic characters included the presence of numerous starch grains in the parenchyma; in the 
peripheral part, brachisclereides were often found; and in the center of the conducting bundles, well-developed sclerenchyma cells. The structure of a leaf was also characterized by the presence of numerous round-shaped inclusions with liquid contents. The stomatal apparatus was of an anomocytic type. The petiole had a radial structure with well-developed numerous bundles, the outer walls of epidermis cells were thickened, the cuticle covering the petiole was uniformly thickened. Repositories were absent in all organs. The characteristic features of the anatomical structure of roots, leaves, and petioles point to the characteristics of mesoxerophytic and calcephytic plants, which also include the species under study. The data obtained can be used in the future for diagnostics of $C$. tatarica raw material of, and in the study of the phytochemical composition of this species.

\section{References}

1. Leppik E., White G. (1975) Preliminary Assessment of Crambe germplasm resources. Euphyti$c a$, vol. 24, pp. 681-689.

2. Khalilov I.I. (1992) Monografija roda Srambe L. [Monograph of the genus Crambe L.]. Abstract for the degree of candidate of biological sciences. St. Petersburg, p. 19.

3. Prina A. (2009) Taxonomic review of the genus Crambe sect. Crambe (Brassicaceae, Brassiceae). Anales del Jardín Botánico de Madrid, vol. 66, no. 1, pp.7-24.

4. Abdulina S.A. (1999) Spisok sosudistyh rastenij Kazahstana [Checklist of vascular plants of Kazakhstan / ed. R.V. Kamelin] / pod red. R.V. Kamelina. Almaty, p. 187.

5. Krasnaya kniga Kazaxstana. Tom 2. Chast 1. Rasteniya (2014) [The Red Data Book of Kazakhstan vol. 2. Part I. Plants]. Almaty, p. 452.

6. Mihajlova O.A., Biryuleva E.G. (2013) Osobennosti anatomicheskogo stroeniya vegetativnyh organov nekotoryh ohranyaemyh vidov roda Crambe L. [Features of Anatomical Structure of the Vegetative Organs of Some Protected Species from Genus Crambe L.]. Byuleten' DNBS, 2013, no. 106, pp. 83-88.

7. Gouz G.V. (2016) The spatial distribution of Crambe tataria (Brassicaceae) across Striltsivsky steppe. Proceedings of the 4th international conference "Rare plants and fungi of Ukraine and adjacent areas: implementing conservation strategies". Kyiv, PALYVODA A.V., pp. 67-69.
8. Flora Kazakhstana / pod red. N.V. Pavlova [Flora of Kazakhstan / ed. N.V. Pavlov] (1961), Alma-Ata: AN KazSSR, no. 4, pp. 304-305.

9. Chervona kniga Ukraïni. Roslinnij svit / pid. red. Ya. P. Diduxa [The Red Book of Ukraine. Vegetable world / ed. J.P. Didukh] (2009), K.: Globalkonsalting, p. 912.

10. Pânzaru P., Negru A., Izverschi T. (2002) Taxoni rari din flora Republicii Moldova. Chişinău, $148 \mathrm{p}$.

11. Palmer C.D., Keller W.A. (2011) Somatic embryogenesis in Crambe abyssinica Hochst. ex R.E. Fries using seedling explants. Plant Cell Tissue and Organ Culture, vol. 104, no 1, pp. 91-100.

12. Vargas-Lopez J. M., Wiesenborn D., Tostenson K., Cihacek L. (1999) Processing of Crambe oil and isolation of erucic acid. Journal of the American Oil Chemists' Society, vol. 76, no. 1, pp. 801-809.

13. Capelle A., Tittonel E.D. (1999) Crambe, a potential non-food oil crop. Production. Agro Food Industry Hi-Tech, vol. 10, no. 1, pp. 22-27.

14. Szmatoła M., Chrobak J., Grabowski R., Iłowska J., Woch J., Szwach I., Semeniuk I., Drabik J., Wrona M., Kozdrach R., Orlińska B., Grymel M. (2018) Spectroscopic methods in the evaluation of modified vegetable base oils from Crambe abyssinica. Molecules, vol. 23, no. 12, pp. 1-18.

15. Tito G.A., Chaves L.H.G., Fernandes J.D., Monteiro D.R., Vasconcelos A.C.F.D. (2014) Effect of copper, zinc, cadmium and chromium in the growth of Crambe. Agricultural Sciences, vol. 5, pp. 975-983.

16. Werner E.T., Milanez C.R.D., Gontijo A.B.P.L., Soares T.C.B., Amaral J.A.T. (2018) Leaf anatomy changes related to cultivate in vivo and in vitro and during pre-acclimatization of Crambe abyssinica Hochst. Plant Cell Cult Micropropag., vol. 14, no. 1 , pp. 10-17.

17. Nigmatullaev B.A., Rahmatov H.A., Ohunov I.I., Karimov U.T., Aripova S.F. (2017) Rasproctranenie i syr'evye zapasy Crambe kotschyana i C. orientalis (sem. Brassicaceae) v Uzbekistane [Distribution and raw materials reserves of Crambe kotschyana and C. orientalis (fam. Brassicaceae) in Uzbekistan]. Uzbekskij biologicheskij zhurnal, no. 1,. pp.61-70.

18. Duschanova G.M., Ohunov I.I., Karimov U.T., Aripova S.F. (2017) Anatomy of vegetative organs of Crambe kotschyana Boiss. (Brassicaceae). Uzbekskij biologicheskij zhurnal, no. 4, pp. 47-55.

19. Komplekcioglu N., Karaman S., Ilcim A. (2008) Oil composition and some morphological 
characters of Crambe orientalis var. orientalis and Crambe tataria var. tataria from Turkey. Nat Prod Res., vol. 22, no. 6, pp. 525-532.

20. Tutus Ah., Komplekcioglu N., Karaman S., Mehmet A. (2010) Chemical Composition and Fiber Properties of Crambe orientalis and C. tataria. Int J Agric Biol., vol. 12, pp. 286-290.

21. Pushkarova N., Kalista M., Kharkhota M., Rakhmetov Dzh., Kuchuk M. (2016) Crambe tataria Sebeók seeds and plants grown in vitro and in vivo fatty acid composition comparison. Potravinarstvo. vol. 10, no. 1. pp. 494-498.

22. Ajpeisova S.A. (2012) Konspekt flory`Aktyubinskogo floristicheskogo okruga [Floristic complexes of Aktobe floristic district]. Aktobe, p. 175.

23. Ajpeisova S.A. (2016) Floristicheskie kompleksy` Aktyubinskogo floristicheskogo okruga [Floristic complexes of Aktobe floristic district]. Aktobe, p. 160 .

24. Izbastina K.S., Kurmanbaeva M.S., Bazargalieva A.A., Erezhepova N.Sh., Aldibekova A.R.
(2018) Floristicheskij sostav rastitel'nyh soobshhestv s uchastiem populjacii redkogo vida Anthemis trotzkiana Claus v Aktjubinskoj oblasti [Floristic composition of plant communities with the participation of a population of a rare species Anthemis trotzkiana Claus in the Aktobe region]. Exp Biol., vol. 74, no. 1, pp. 4-19.

25. Ajpeisova S.A. (2011) Redkie i ischezajushhie rastenija Aktjubinskoj oblasti [Rare and endangered plants of Aktobe region]. Aktobe, p. 165.

26. Barykina R.P. (2004) Spravochnik po botanicheskoj mikrotehnike. Osnovy i metody [Handbook of botanical microtechnique. Basics and methods]. M.: Izd-vo Moskovskogo universiteta, p. 312.

27. Gosudarstvennaja farmakopeja Respubliki Kazahstan, vol. 1. (2008) [State Pharmacopoeia of the Republic of Kazakhstan, T. 1]. Almaty, p. 592.

28. Gosudarstvennaja farmakopeja Respubliki Kazahstan, vol. 2. (2009) [State Pharmacopoeia of the Republic of Kazakhstan, T. 2]. Almaty, p. 804. 